\title{
Combined Application of Ozone and Hydrogen Peroxide to Degrade Diesel Contaminants in Soil and Groundwater
}

\author{
Wen-Yu Chen ${ }^{1}$, Prakash Pokhrel ${ }^{1,2} \mathbb{D}$, Ying-Shun Wang ${ }^{2}$, Sheng-Lung Lin ${ }^{2, *}$ and Min-Hsin Liu ${ }^{2, * \mathbb{D}}$ \\ 1 Department of Applied Chemistry, College of Science and Engineering, Chaoyang University of Technology, \\ Taichung 413310, Taiwan; wen-yea@yahoo.com.tw (W.-Y.C.); greenpokhrel@gmail.com (P.P.) \\ 2 Department of Environmental Engineering and Management, College of Science and Engineering, Chaoyang \\ University of Technology, Taichung 413310, Taiwan; hotdog@yahoo.com.tw \\ * Correspondence: sllin@cyut.edu.tw (S.-L.L.); jliu@cyut.edu.tw (M.-H.L.)
}

Citation: Chen, W.-Y.; Pokhrel, P.; Wang, Y.-S.; Lin, S.-L.; Liu, M.-H. Combined Application of Ozone and Hydrogen Peroxide to Degrade Diesel Contaminants in Soil and Groundwater. Water 2021, 13, 3404. https://doi.org/10.3390/w13233404

Academic Editor: Jenn Kai Tsai

Received: 30 August 2021

Accepted: 25 November 2021

Published: 2 December 2021

Publisher's Note: MDPI stays neutral with regard to jurisdictional claims in published maps and institutional affiliations.

Copyright: (c) 2021 by the authors. Licensee MDPI, Basel, Switzerland. This article is an open access article distributed under the terms and conditions of the Creative Commons Attribution (CC BY) license (https:// creativecommons.org/licenses/by/ $4.0 /)$.

\begin{abstract}
Environmental pollution has been a major concern in recent times, and soil and groundwater pollution are areas which have received particular focus. This has led to the development of various remediation techniques such as excavation, soil vapor extraction, bioremediation, chemical oxidation, and so on. Among all remediation techniques, chemical oxidation has been proven to be the most effective and feasible technique around the world. In this study, various combinations of ozone and hydrogen peroxide were used to treat diesel-contaminated soil and groundwater in an experimental setup. Experimental soil and groundwater were prepared with properties similar to the contaminated soil. An ozone generator and a pump injection system were deployed for combining ozone and hydrogen peroxide. Five different experiment batches were prepared based on the hydrogen peroxide concentration and its ratio to the soil. The diesel concentration in the water dropped from $300 \mathrm{mg} / \mathrm{L}$ to $7 \mathrm{mg} / \mathrm{L}$ in the first hour of treatment, which dropped below the detection limit $(0.01 \mathrm{mg} / \mathrm{L})$ thereafter. Similarly, $63.9 \%$ degradation was achieved with the combined sparging of ozone and hydrogen peroxide in the soil. Ozone combined with $7 \%$ hydrogen peroxide was the most promising combination for removing the contaminants. In addition, this research explored the hydroxyl radical conversion rate of ozone and the perozone, the difference in order of magnitude is greater than one which shows that the perozone has better oxidation capacity than ozone only. The findings of this study show that combining ozone with hydrogen peroxide is a competent and feasible onsite remediation method for diesel contaminants in soil and groundwater. Thus, this method can be applied in local gas stations, accidental spillage sites, and small-scale refineries for onsite treatment in a cost-effective and technically sound way within a short time span.
\end{abstract}

Keywords: total petroleum hydrocarbon; ozone; hydrogen peroxide; chemical oxidation; groundwater; soil

\section{Introduction}

Soil is home to thousands of species and billions of populations [1]. It plays a pivotal role in ecosystem regulation and support [2-4]. Most species, including human beings, depend on soil in one way or another for food and habitat [5]. However, in recent years, soil, along with groundwater, has been contaminated by numerous anthropogenic activities altering its physical and chemical properties. This has serious effects on the biogeochemical cycles [6-8].

The emerging technologies that are replacing hydrocarbon-based fuel are revolutionizing the world, yet diesel-based fuels serve as the most commonly used fuel source in transportation and industries and will take years for complete replacement [9]. This fuel source contributes massively to soil and water pollution, as well as air pollution. Oil spills during transport and transfer, industrial wastewater, underground fuel reserve tanks, vehicle service centers, etc., are major sources of diesel contamination in soil and water [10]. The accidental spillage from oil transport tankers is another cause of local soil and groundwater 
pollution in the countries where there are no underground pipeline facilities. Gas stations and small-scale oil refineries discharge diesel-based wastes improperly, for example, in Sulaymaniyah city, Iraq [11]. Thus, the above-mentioned factors are the major sources of diesel contamination in soil which increases the soil carbon, causing an imbalance in the soil nutrient, resulting in the ecological destruction of the environment, ecology, and human health [12-15].

Due to the continuous operation of the above-mentioned leaking sources and space constraints, in situ remediation is desired [10]. The trend of using advanced oxidation processes and bioremediation for diesel contamination has been increasing in recent years because of its higher efficiency and lower environmental impact. The oxidants widely used for this process include hydrogen peroxide $\left(\mathrm{H}_{2} \mathrm{O}_{2}\right)$, permanganate $\left(\mathrm{MnO}_{4}{ }^{-}\right)$, ozone $\left(\mathrm{O}_{3}\right)$, persulfate $\left(\mathrm{S}_{2} \mathrm{O}_{8}{ }^{2-}\right)$, and Fenton process $(\bullet \mathrm{OH})$. These oxidants convert the organic pollutants either to harmless or less harmful compounds, thereby positively impacting the soil and the environment [16-19].

During the advanced oxidation process, the uniform distribution of oxidants is less likely. When gaseous ozone is used only for oxidation, a high concentration of dysoxidizable contaminants cannot be effectively degraded because of its limited oxidation capacity. The ozone molecule, in contrast, is easily oxidized to hydroxyl radicals $(\bullet \mathrm{OH})$ with strong oxidizing power under the catalysis of hydroxyl ion and it has a redox potential of 2.80 volts [20-22], which is higher than the ozone molecule. A free radical reacts with organic matter mainly through three mechanisms: hydroxy addition, hydrogen abstraction, and electron transfer [23]. Generally, the reaction of the free radicals and organic matters is not selective [24], and besides the oxidation of the compound with an unsaturated bond, the free radicals react with an aliphatic compound with an unsaturated bond. However, during free radical chain reaction, it is easy to react with radical scavengers, such as carbonate, bicarbonate, etc., which hold a great reaction rate with the hydroxyl radicals, thus causing an inhibiting effect on the free radical chain reaction [25].

If gaseous ozone is combined with liquid hydrogen peroxide for chemical oxidation, mutual intensification may produce plenty of hydroxyl radicals to improve their oxidation capacity [26]. Therefore, the perozone reaction is made by combining the ozone with the hydrogen peroxide, and their chemical oxidation capacity is improved by injecting the ozone into the saturated zone and hydrogen peroxide into the unsaturated zone. Therefore, reaction time may be shortened by the production of plenty of hydroxyl radicals during the perozone reaction to improve the contaminant degradation rate and reduce the required ozone $[27,28]$.

Several prior studies have focused on the technique of using ozone and hydrogen peroxide for oxidation-reduction to treat diesel contaminants in soil and water [29-32]. There are diverse studies that report the combination of these two to treat various pollutants [33-35], while limited studies are focused on soil and water treatment [36]. Thus, this study was carried out to determine the effectiveness of diesel degradation in soil and groundwater using various proportions of hydrogen peroxide combined with ozone. Our study assumes that the experimental setup characterizes the physio-chemical properties of the soil and water at the actual contaminated site. The findings of this study will establish a strong stand for policymakers and concerned personnel to establish an onsite remediation setup that is economically feasible and technically sound.

\section{Materials and Methods}

\subsection{Experimental Procedure and Design}

Diesel contaminated soil and groundwater samples were collected from one of the contaminated sites in central Taiwan. The samples were analyzed to determine their chemical and physical properties. Experimental soil was prepared with similar chemical and physical properties since soil from the contaminated site was not permitted to collect in large quantities. A high-density polyethylene (HDPE) tank with a volume of $2.83 \times 105 \mathrm{~cm}^{3}$ was built and was equipped with a good casing and screen at the center. The 
tank was then filled with $150 \mathrm{~kg}$ of artificially contaminated soil [37] and $57 \mathrm{~L}$ of water to form a saturated layer (Figure 1). Then, the top of the contaminated soil was covered with non-contaminated soil and the tank was sealed with ethylene propylene diene monomer rubber.

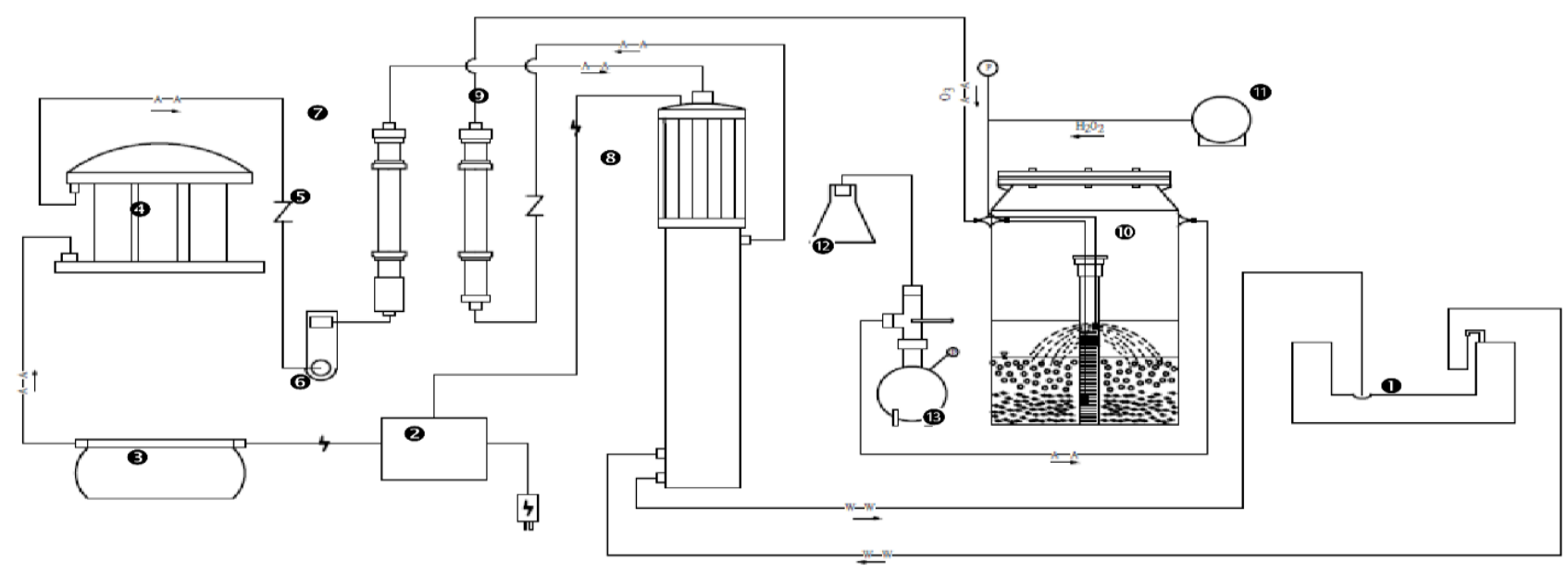

Figure 1. Schematic diagram experimental setup. (1) Cooling water tank; (2) High voltage transformer; (3) Air compression pump; (4) Oxygen generator; (5) Check valve; (6) Flow control valve; (7) Oxygen flow meter; (8) Quartz electrode; (9) Ozone flow meter; (10) Reaction tank; (11) Pump; (12) KI solution; (13) Air compressor.

Ozone gas used in the experiment was generated in the laboratory using an ozone generator (EMEC, OXL-50) which uses a quartz tube discharge method. In this method, atmospheric air is used instead of pure oxygen, which results in the formation of trace nitrous oxide influencing the $\mathrm{pH}$ of the water [38]. Similarly, a pump injection system was established to inject hydrogen peroxide into the sample soil.

\subsection{Operating Conditions of Ozone and Hydrogen Peroxide Reaction System}

A preliminary study was conducted with different flow rates, viz. $5 \mathrm{~L} / \mathrm{min}, 7.5 \mathrm{~L} / \mathrm{min}$, $10 \mathrm{~L} / \mathrm{min}, 15 \mathrm{~L} / \mathrm{min}$, and $18 \mathrm{~L} / \mathrm{min}$ to determine the optimum production $(288 \mathrm{mg} / \mathrm{L}$ at $10 \mathrm{~L} / \mathrm{min}$ ) and minimum emission ( $8 \mathrm{~h}$ moving average, $0.04 \mathrm{ppm}$ ). Thus, the ozone with a concentration of $288 \mathrm{mg} / \mathrm{L}$ was sparged into the sampling tank for $1 \mathrm{~h}$ with a flow rate of $10 \mathrm{~L} / \mathrm{min}$. The sample was taken after $23 \mathrm{~h}$ for analysis and this process was carried out 12 and 24 times. The experiment was conducted with five different settings based on the use of hydrogen peroxide concentration and its ratio to the soil by weight (Table 1). Three different concentrations of hydrogen peroxide (4\%,7\%, and $10 \%)$ and two different $\mathrm{H}_{2} \mathrm{O}_{2}$ and soil weight ratios (1:50 and 1:100) were used in this study. The three different $\mathrm{H}_{2} \mathrm{O}_{2}$ concentrations were experimented with the same $\mathrm{H}_{2} \mathrm{O}_{2}$ :soil ratio (1:50), one sample with ozone only, and the remaining sample with $7 \% \mathrm{H}_{2} \mathrm{O}_{2}$ in 1:100 $\mathrm{H}_{2} \mathrm{O}_{2}$ :soil ratio (Table 1). The experiment was repeated 24 times for two combinations viz. soil treated with ozone only and ozone with $7 \% \mathrm{H}_{2} \mathrm{O}_{2}$ and 1:100 $\mathrm{H}_{2} \mathrm{O}_{2}$ :soil ratio (Batch 1 and 5) and the rest were treated 12 times (Batch 2, 3, and 4).

Table 1. The different experimental scenarios used in the study.

\begin{tabular}{cccc}
\hline $\begin{array}{c}\text { Initial Diesel Concentration } \\
(\mathbf{m g} / \mathbf{k g})\end{array}$ & Experiment ID & $\begin{array}{c}\mathbf{H}_{\mathbf{2}} \mathbf{O}_{\mathbf{2}} \\
\text { Concentration }\end{array}$ & $\begin{array}{c}\mathbf{H}_{\mathbf{2}} \mathrm{O}_{2} \text { :Soil Ratio } \\
\text { (Weight Basis) }\end{array}$ \\
\hline $\mathbf{2 4 , 2 0 0}$ & Batch 1 & $0 \%$ & $\mathrm{x}$ \\
$\mathbf{2 4 , 2 2 3}$ & Batch 2 & $4 \%$ & $1: 50$ \\
$\mathbf{1 7 , \mathbf { 1 1 5 }}$ & Batch 3 & $7 \%$ & $1: 50$ \\
$\mathbf{1 4 , 2 8 6}$ & Batch 4 & $10 \%$ & $1: 50$ \\
$\mathbf{3 2 , 1 3 1}$ & Batch 5 & $7 \%$ & $1: 100$ \\
\hline
\end{tabular}




\subsection{Sampling and Analysis}

The soil sample was taken from distances of $5 \mathrm{~cm}, 15 \mathrm{~cm}$, and $30 \mathrm{~cm}$ from the central gas injection tube. Then the sample was mixed well to maintain homogeneity. The residual diesel concentration and $\mathrm{pH}$ of the soil were analyzed before and after the treatment. Similarly, $\mathrm{pH}$, residual diesel concentration, oxidation-reduction potential (ORP), and conductivity of groundwater were also analyzed. All the samples were tested three times and the mean was used in the results [39]. The major component of diesel fuel included straight-chain hydrocarbons (C10-C25) and branched-chain hydrocarbons, such as pristane and phytane. Therefore, the effectiveness of the hydrogen peroxide and ozone treatment system was analyzed based on overall diesel-range, total petroleum hydrocarbons (TPH-d), C13, C17, pristane, C18, phytane, and C23 degradation. The Mann Kendall trend test, which is a non-parametric statistical test that does not require the sample to follow a definite distribution pattern, was used to analyze the degradation of diesel over time [40-42].

The concentration of TPH-d was measured using a gas chromatograph (GC) (Perkin Elmer Clarus 500) with GS-Alumina columns (30 $\mathrm{m} \times 0.32 \mathrm{~mm} \times 0.1 \mu \mathrm{m}$, Agilent) and a flame ionization detector. Ultra-high purity grade nitrogen $(99.999 \%)$ was used as the carrier gas and supplemental gas in the analysis at a flow rate of $30 \mathrm{~mL} / \mathrm{min}$. The temperatures of the injection port and detector were $300^{\circ} \mathrm{C}$ and $330^{\circ} \mathrm{C}$, respectively, which was increased from $50{ }^{\circ} \mathrm{C}$ at a controlled rate of $10^{\circ} \mathrm{C} / \mathrm{min}$. The final temperature was maintained for $7 \mathrm{~min}$. The analysis and QA/QC were carried out according to Taiwan Environmental Protection Agency (Taiwan EPA) procedures (NIEA S703.62B) [43]. The precision and accuracy were determined by triplicate analysis of QC samples at low $(1250 \mathrm{mg} / \mathrm{L})$ and high $(25,000 \mathrm{mg} / \mathrm{L})$ concentrations by overall mean, relative standard deviation ( $\%$ RSD), and percent deviation ( $\%$ DEV). The $\%$ RSD for precision was comprised below $10.6 \%$, and $\%$ DEV for accuracy was between 3.0 and $7.0 \%$.

\subsection{Hydroxyl Radical Conversion Rate}

This study has explored the conversion rate of hydroxyl radicals after reacting with ozone and a combination of both ozone and hydrogen peroxide, this combination hereafter is referred to as the perozone. For this experiment, the ozone flow rate, concentration, and mass flow rate were maintained at $5 \mathrm{~L} / \mathrm{min}, 1.94 \mathrm{mg} / \mathrm{L}$, and $9.702 \mathrm{mg} / \mathrm{min}$. For the perozone study, $1 \mathrm{~mL}$ of $7 \%$ hydrogen peroxide was added to the experimental setup before ozone sparging. Since hydroxyl radical $(\bullet \mathrm{OH})$ is difficult to detect, 4-Chlorobenzoic acid $(p \mathrm{CBA})$ was used as a probe compound. 4-Chlorobenzoic acid $(p \mathrm{CBA})$ reacts easily with hydroxyl radical $(\bullet \mathrm{OH})$ and does not react with ozone, making the detection facile. The initial concentration of $p C B A$ was $10 \mathrm{mg} / \mathrm{L}$, which was fully reacted in $70 \mathrm{~s}$. The reaction mechanism is given in Equations (1)-(3) [44].

$$
\frac{-d[p \mathrm{CBA}]}{d t}=k_{\frac{\bullet \mathrm{OH}}{p \mathrm{CBA}}}[p \mathrm{CBA}][\bullet \mathrm{OH}]
$$

where, $\mathrm{k} \bullet \mathrm{OH} / p \mathrm{CBA}$ is reaction rate constant whose value is $5 \times 109 \mathrm{M}^{-1} \mathrm{~s}^{-1}$, and ozone and $\bullet \mathrm{OH}$ reaction pathway can be predicted by ozone reaction kinetics and the ratio of hydroxyl radical exposure to ozone exposure $\left(R_{c t}\right) ; R_{c t}$ can be expressed as in Equation (2).

$$
R_{c t}=\frac{\int[\bullet \mathrm{OH}]}{\int\left[\mathrm{O}_{3}\right] d t}
$$

where $\int\left[\mathrm{O}_{3}\right] d t$ is ozone concentration over time. Substituting Equation (1) into Equation (2), the following Equation (3) was obtained. Thus, using Equation (3), $R_{c t}$ was calculated and oxidation capacity was determined.

$$
\ln \left(\frac{[p \mathrm{CBA}]}{[p \mathrm{CBA}]_{0}}\right)=-k_{\bullet} \mathrm{OH} / p \mathrm{CBA} R_{c t} \int\left[\mathrm{O}_{3}\right] d t
$$




\section{Results and Discussion}

\subsection{Background Investigation}

The sample soil and groundwater were taken from a polluted site in central Taiwan. The results of soil texture analysis showed that the soil was composed of $75 \%$ sand, $15 \%$ silt, and $10 \%$ clay and, thus, is classified as sandy loam by the United States Department of Agriculture (USDA). Similarly, the bulk density, porosity, and hydraulic conductivity of the soil were $1.58 \mathrm{~g} / \mathrm{cm}^{3}, 41 \%$, and $1.071 \times 10^{-3} \mathrm{~cm} / \mathrm{sec}$, respectively. The diesel concentration in the contaminated soil and groundwater was found to be $1600 \mathrm{mg} / \mathrm{kg}$ and $45 \mathrm{mg} / \mathrm{L}$, respectively. To determine the effect of perozone on diesel degradation, diesel was sprinkled in the soil and groundwater to achieve an initial diesel concentration between 14,000 and $32,131 \mathrm{mg} / \mathrm{kg}$ in the soil and $300 \mathrm{mg} / \mathrm{L}$ in the groundwater. Constant concentration could not be achieved since the concentration of diesel kept fluctuating over time [39].

\subsection{Effect of Ozone and Perozone on Oxidation-Reduction Potential of Groundwater}

In this study, contaminated groundwater was treated with ozone only and with perozone in different soil ratios (Table 1 ) to observe the effect on ORP. The ORP value of the Batch 1 sample spiked from $-138 \mathrm{mV}$ to $247 \mathrm{mV}$ in the first hour, which descended after $3 \mathrm{~h}$, then increased to $257 \mathrm{mV}$ and showed a gradual increment reaching the value of $276 \mathrm{mV}$ in the last $12 \mathrm{~h}$ (Figure 2). There was a gradual increment in the ORP value for Batch 5 for the first $3 \mathrm{~h}$ from $250 \mathrm{mV}$ to $559 \mathrm{mV}$ which then decreased gradually to $514 \mathrm{mV}$. The values were inconsistent for the remaining batches with the increased final values. Thus, it was observed that the ozone only treatment could quickly increase the ORP compared to the perozone treatment. For the perozone treatment, the highest efficiency can be achieved within the first $4 \mathrm{~h}$ of treatment. The greater the ORP, the stronger the oxidation potential, thus, the higher the efficiency of organic pollutants removal [45].

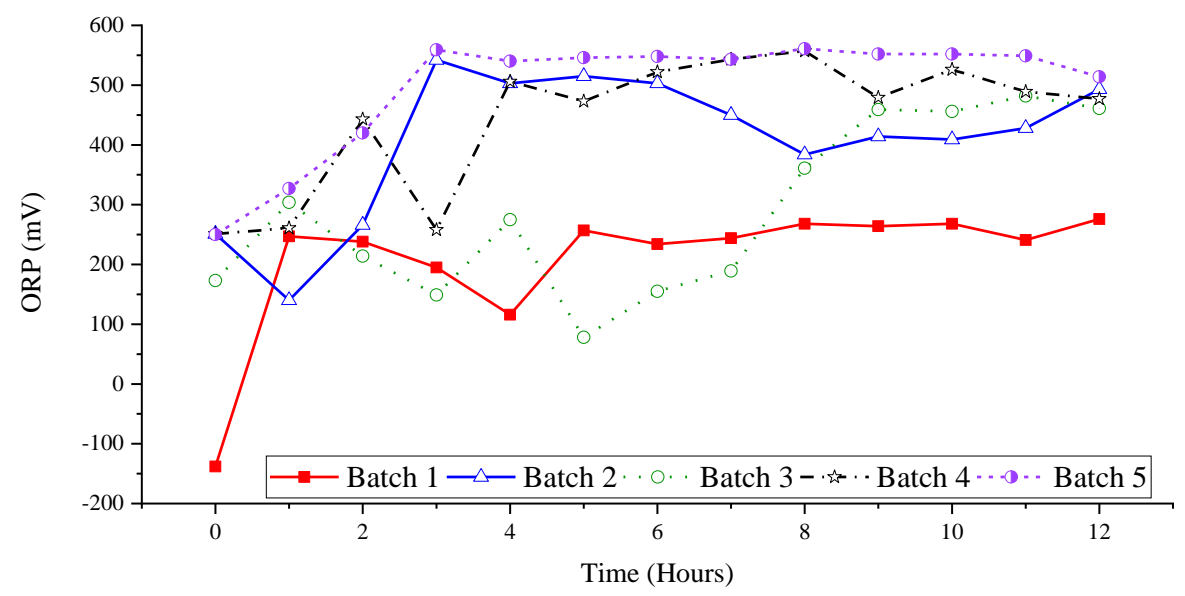

Figure 2. Effect of ozone and perozone on ORP of groundwater over time.

\subsection{Effect of Ozone and Perozone on $\mathrm{pH}$ Value of Groundwater}

Groundwater was treated with ozone and perozone to understand the effect on $\mathrm{pH}$. The results showed that the groundwater was acidified in the first hour of treatment in all the batches. There was a fluctuation in the $\mathrm{pH}$ value after 8 hours of treatment in Batches 1, 3 , and 4 , whereas in the remaining batches, the $\mathrm{pH}$ value was almost constant until $12 \mathrm{~h}$. However, the $\mathrm{pH}$ after $12 \mathrm{~h}$ of treatment was almost equal to all the batches (Figure 3). The ozone has high ORP and thus oxidizes the organic matter forming organic acids, aldehydes, and ketoacids. This mechanism increases the acidity of water, resulting in the decrease in the $\mathrm{pH}[46,47]$. 


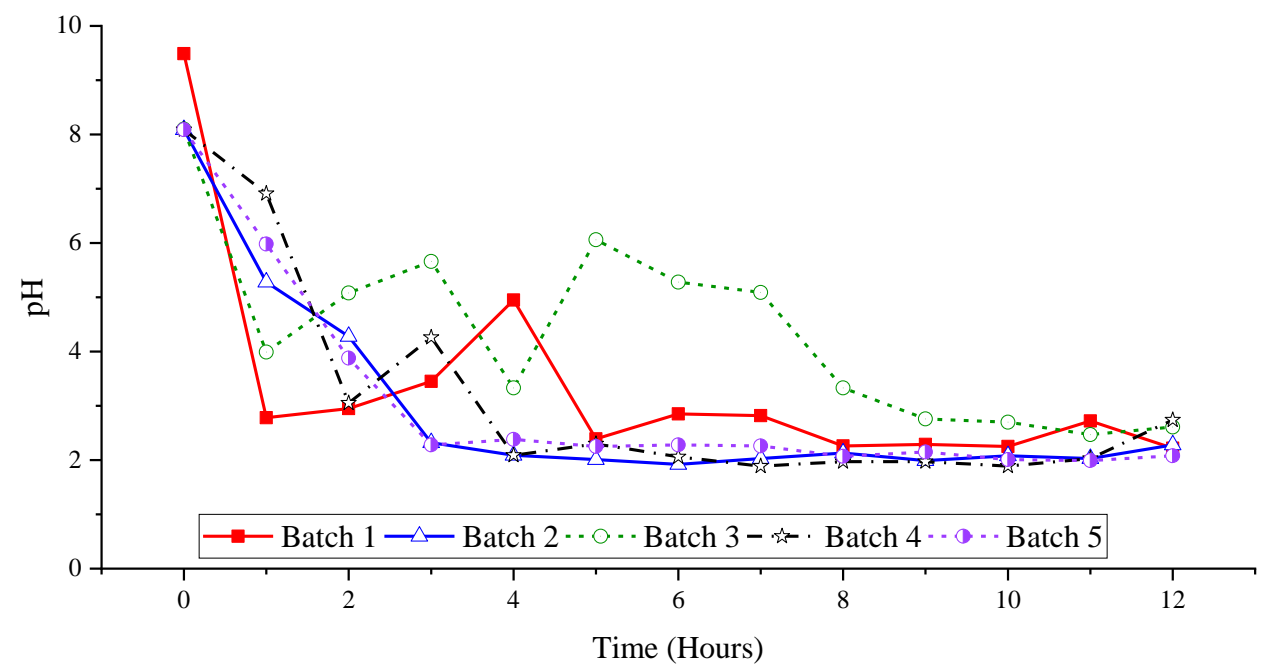

Figure 3. Effect of ozone and perozone sparging on $\mathrm{pH}$ value of groundwater.

The anion concentration of the groundwater collected from the contaminant site was analyzed using ion chromatography with a conductivity detector after 1 and $6 \mathrm{~h}$ of treatment with ozone (Table 2). There was a high increase in nitrate, chloride, fluoride, and sulfate ion concentration after the ozone treatment, which lead to a decrease in the $\mathrm{pH}$ value. Since this system used the ozone purified by separating nitrogen from the air, the remaining nitrogen may have formed trace nitrogen oxide. The results show that the acidification of groundwater after ozone injection was because of the generation of a high concentration of nitrate ions. The $100 \mathrm{~L}$ reaction tank used in this study may have caused the accumulation of nitrate ions in the groundwater due to the production of nitrogen oxides in the experimental system.

Table 2. Anion concentration before and after ozone sparging in the groundwater.

\begin{tabular}{cccc}
\hline Items & $\begin{array}{c}\text { Groundwater w/o } \\
\text { Ozone Sparging } \\
(\mathbf{m g} / \mathbf{L})\end{array}$ & $\begin{array}{c}\text { Groundwater after 1 h } \\
\text { Ozone Sparging } \\
(\mathbf{m g} / \mathrm{L})\end{array}$ & $\begin{array}{c}\text { Groundwater after 6 h } \\
\text { Ozone Sparging } \\
(\mathbf{m g} / \mathbf{L})\end{array}$ \\
\hline $\mathrm{pH}$ & 9.49 & 2.85 & 2.22 \\
$\mathrm{Br}^{-}$ & $<0.01$ & $<0.01$ & $<0.05$ \\
$\mathrm{BrO}_{3}{ }^{-}$ & $<0.0006$ & $<0.0006$ & $<0.0006$ \\
$\mathrm{NO}_{3}{ }^{-}$ & 0.80 & 380 & 1090 \\
$\mathrm{PO}_{4}{ }^{-}$ & 0.50 & $<0.013$ & 0.60 \\
$\mathrm{Cl}^{-}$ & 6.80 & 9.80 & 20.2 \\
$\mathrm{~F}^{-}$ & $<0.013$ & 0.50 & 1.00 \\
$\mathrm{SO}_{4}{ }^{-}$ & 5.20 & 14.8 & 71.5 \\
$\mathrm{NO}_{2}{ }^{-}$ & $<0.011$ & 1.00 & 1.90 \\
\hline
\end{tabular}

\subsection{Effect of Ozone and Perozone on Diesel Degradation of Groundwater}

The effect of ozone and different combination of perozone was investigated in this study. The diesel concentration of groundwater dropped significantly within the first hour of ozone treatment. The diesel contaminant remained undetected in Batches 4 and 5 during the first hour. In Batch 1, there was an inconsistency in the TPH-d concentration whereas, in Batch 3, the concentration decreased from $300 \mathrm{mg} / \mathrm{L}$ to $7 \mathrm{mg} / \mathrm{L}$ in the first hour and then remained below the detection limit throughout the testing time. In Batch 5, the concentration was below the detection limit from the first hour of sparging (Figure 4). After $12 \mathrm{~h}$, the concentration of TPH-d was below the detection limit. The detection limit of the instrument was below $0.01 \mathrm{mg} / \mathrm{L}$. The result shows that perozone is effective at treating diesel contaminants in groundwater in a short time span. This result is achieved by the higher reaction rate between hydroxyl radical and diesel hydrocarbons. The finding of this 
study is supported by Kong et al.'s study [48] which recommended further study on the ratio for use of $\mathrm{H}_{2} \mathrm{O}_{2}$ and $\mathrm{O}_{3}$.

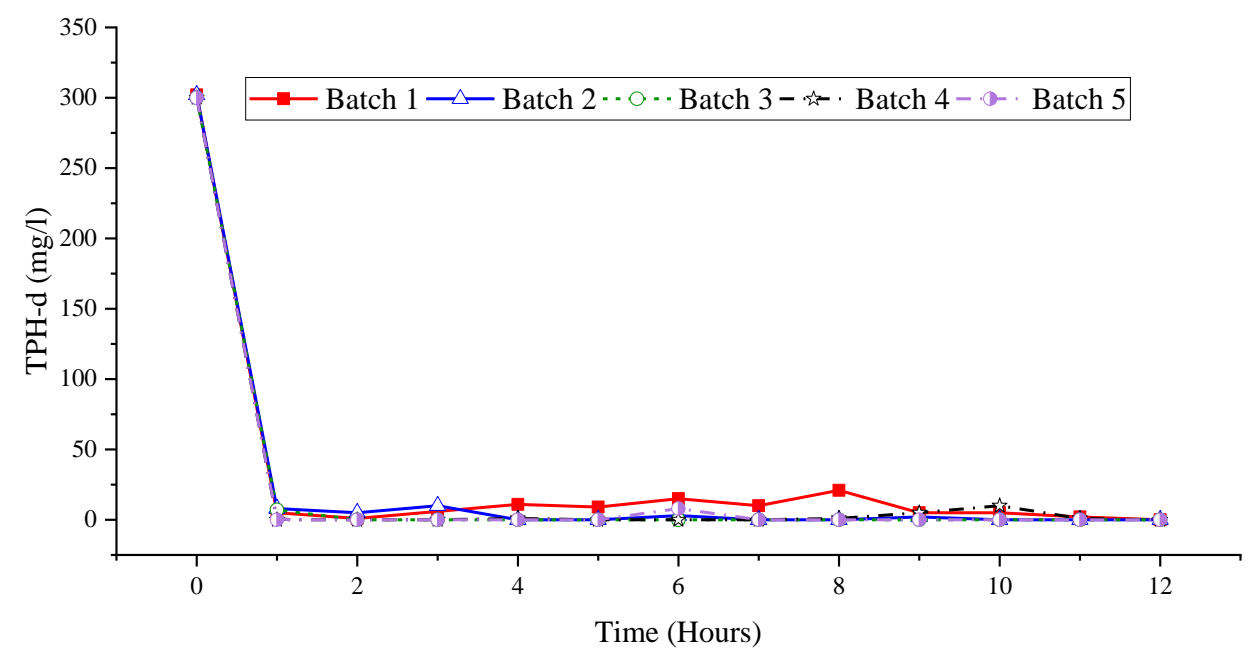

Figure 4. Degradation of diesel in groundwater over time by ozone and perozone sparging.

\subsection{Effect of Ozone and Perozone in Diesel Contaminated Soil}

The diesel degradation in the soil was analyzed on a decreased TPH-d concentration basis. None of the batches showed a regular trend in diesel degradation (Figure 5). There was inconspicuous degradation of diesel contaminant in Batches 1, 2, and $4(37.27 \%, 37.22 \%$, and $36.96 \%$, respectively), whereas copious degradation was found in Batches 3 and 5 $(63.9 \%$ and $62.69 \%)$ after $12 \mathrm{~h}$ of ozone and perozone sparging. The efficiency of diesel degradation was increased by $15.13 \%$ in Batch 5 when the sparging time was increased to $24 \mathrm{~h}$ whereas, in Batch 1, the efficiency was increased by $20.57 \%$. Hence, the highest degradation rate was achieved in Batch 3, which is the combination of ozone and $7 \% \mathrm{H}_{2} \mathrm{O}_{2}$ concentration with $\mathrm{H}_{2} \mathrm{O}_{2}$ :soil ratio 1:50. Thus, this provides the optimum ratio of $\mathrm{H}_{2} \mathrm{O}_{2}$ and soil with $\mathrm{O}_{3}$ combination for effective removal of diesel contamination from soil. The mechanism which supports this result is supplemented by the results of Bourgin et al., which state that the excessive hydroxyl ion is produced during the reaction and reacts with each other to become stable $\mathrm{H}_{2} \mathrm{O}_{2}$ [36].

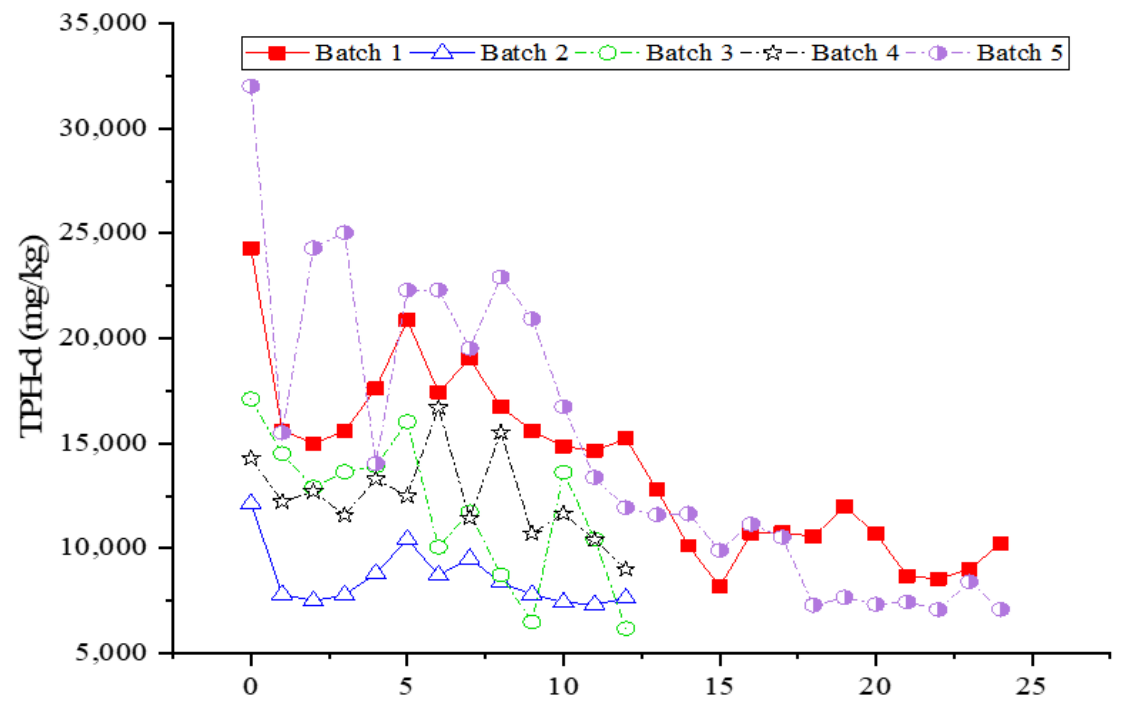

Figure 5. Degradation of diesel (TPH-d concentration) in soil by ozone and perozone treatment. 


\subsection{Effect of Ozone and Perozone in C13, C17, Pristane, C18, Phytane, and C23 Degradation}

The degradation effect on the specific hydrocarbons in diesel, such as C13, C17, pristane, C18, phytane, and C23 components, were analyzed by ozone and perozone sparging, and the degradation efficiency is expressed by the variation trend of the relative concentration of individual components. The testing results of ozone sparging (Batch 1) are shown in Figure 6a. A good degradation effect on all straight-chain hydrocarbons was observed by ozone sparging during the first hour, whereas branched-chain hydrocarbons such as pristane $(\mathrm{Pr})$ and phytane $(\mathrm{Ph})$ could not be degraded even after $15 \mathrm{~h}$ of sparging.
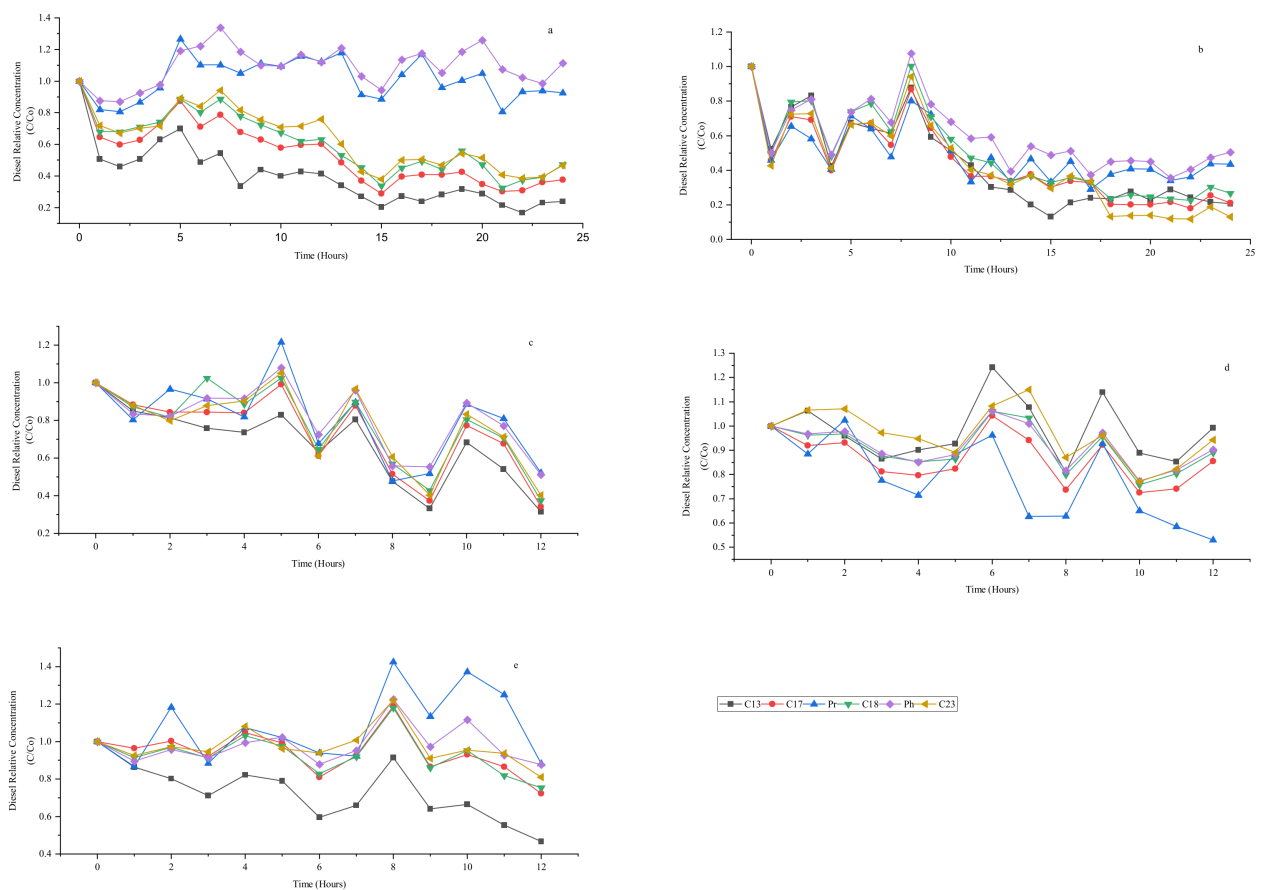

$-\mathrm{C} 13-0-\mathrm{C} 17-\mathrm{A}-\mathrm{Pr}-\mathrm{C}-\mathrm{C} 18-\mathrm{Ph}-\mathrm{C}-\mathrm{C} 23$

Figure 6. Change of relative concentration of specific hydrocarbons after treatment, Batch 1 (a), Batch 5 (b), Batch 3 (c), Batch 2 (d), and Batch 4 (e).

In the first hour of perozone sparging, Batch 5 showed a good efficiency for both branched and straight-chained hydrocarbons degradation. The relative concentration of hydrocarbons was 0.42 after $12 \mathrm{~h}$ and 0.29 after $24 \mathrm{~h}$, showing significant degradation of hydrocarbons (Figure 6b). In Batch 3, there was gradual oxidation of hydrocarbons and they were degraded by perozone sparging concerning time. The relative concentration of hydrocarbon ranged between 0.31 and 0.52 after $12 \mathrm{~h}$ of the perozone treatment (Figure 6c). In Batches 2 and 4, an inconspicuous degradation effect was observed on hydrocarbon with an average relative concentration of 0.75 and 0.85 , respectively, after $12 \mathrm{~h}$ of treatment (Figure 6d,e).

\subsection{Hydroxyl Radical Conversion Rate $\left(R_{c t}\right)$}

The degradation of $p$ CBA concentration in the ozone and perozone during the hydroxyl radical conversion is shown in Figure 7. The experimental data was used to determine the hydroxyl radical conversion rate $\left(R_{c t}\right)$ for ozone and perozone using Equation (3). The $R_{c t}$ for ozone was $5.18 \times 10^{-10}$, whereas there was an order difference in magnitude for the perozone $\left(5.35 \times 10^{-9}\right)$. Thus, the difference in $R_{c t}$ value shows that the perozone has a higher oxidation capacity, and thus, provides better degradation of diesel contaminants. 


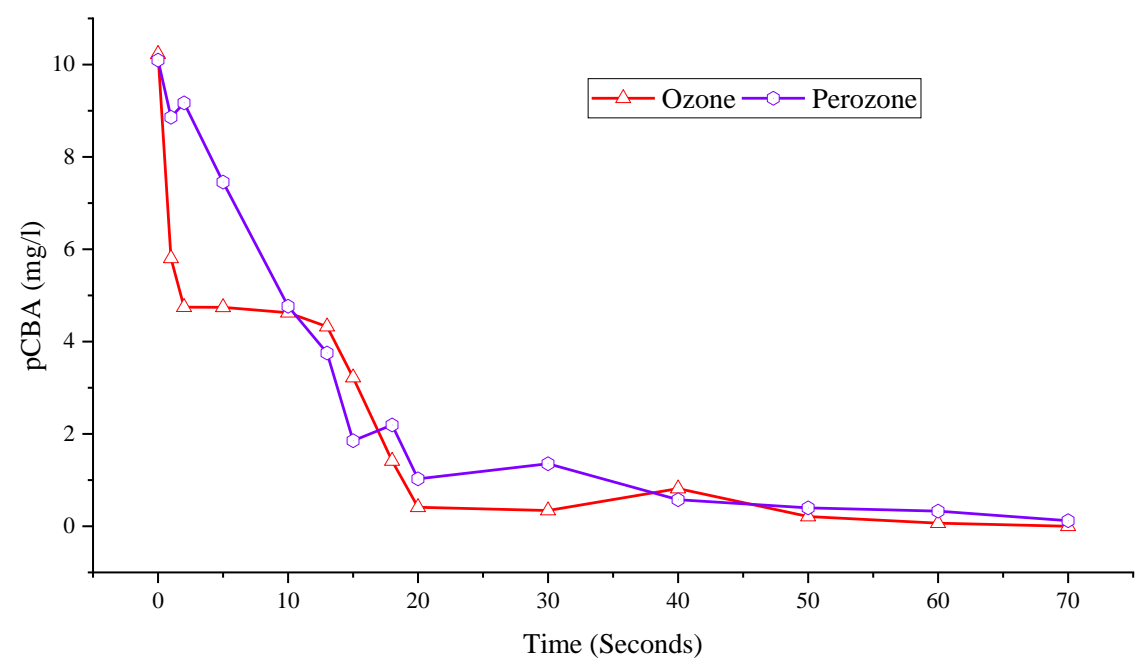

Figure 7. $p$ CBA concentration with respect to ozone sparging time.

\section{Conclusions}

Diesel-contaminated soil and groundwater were treated with ozone and perozone at a laboratory-scale to assess the effectiveness of the removal of contaminants. The results showed that the oxidation capacity of perozone is better than ozone and can be effectively used for treating diesel contaminants in soil and groundwater simultaneously. Moreover, the findings indicated that groundwater can be treated with higher efficiency compared to soil with the same composition of perozone.

The experiment was conducted as a pilot study with $150 \mathrm{~kg}$ of soil and $57 \mathrm{~L}$ of water samples and showed promising results. The total estimated cost of the treatment was USD 1.95. Thus, this method is cost-effective, easy to install, and portable since it uses a small operating area, short duration, and minimal resources. This study shed light on the potential application on onsite contaminated areas such as accidental oil spillage, gas station leakage, small-scale refineries, etc.

Author Contributions: Conceptualization and methodology, M.-H.L. and S.-L.L.; validation, M.-H.L., S.-L.L. and P.P.; formal analysis, W.-Y.C., P.P. and Y.-S.W.; investigation, W.-Y.C. and P.P.; resources and data curation, W.-Y.C., P.P. and Y.-S.W.; writing-original draft preparation, W.-Y.C. and P.P.; writing-review and editing, M.-H.L. and S.-L.L.; supervision, M.-H.L.; funding acquisition, M.-H.L. All authors have read and agreed to the published version of the manuscript.

Funding: This study was funded by a research project supported by the Taiwan EPA (Funding No. 107GA0004002002). The views or opinions expressed in this article are those of the authors and should not be considered as opinions of the Taiwan EPA. Mention of trade names, vendor names, or commercial products does not constitute endorsement or recommendation by Taiwan EPA.

Institutional Review Board Statement: Not applicable.

Informed Consent Statement: Not applicable.

Conflicts of Interest: The authors declare no conflict of interest.

\section{References}

1. Wolters, V. Biodiversity of soil animals and its function. Eur. J. Soil Biol. 2001, 37, 221-227. [CrossRef]

2. Liu, L.; Gudmundsson, L.; Hauser, M.; Qin, D.; Li, S.; Seneviratne, S.I. Soil moisture dominates dryness stress on ecosystem production globally. Nat. Commun. 2020, 11, 4892. [CrossRef]

3. Yang, F.; Zhang, Z.; Barberán, A.; Yang, Y.; Hu, S.; Guo, H. Nitrogen-induced acidification plays a vital role driving ecosystem functions: Insights from a 6-year nitrogen enrichment experiment in a Tibetan alpine meadow. Soil Biol. Biochem. 2021, 153, 108107. [CrossRef]

4. Delgado-Baquerizo, M.; Reich, P.B.; Trivedi, C.; Eldridge, D.J.; Abades, S.; Alfaro, F.D.; Bastida, F.; Berhe, A.A.; Cutler, N.A.; Gallardo, A.; et al. Multiple elements of soil biodiversity drive ecosystem functions across biomes. Nat. Ecol. Evol. 2020, 4, 210-220. [CrossRef] 
5. Brussaard, L.; de Ruiter, P.C.; Brown, G.G. Soil biodiversity for agricultural sustainability. Agric. Ecosyst. Environ. 2007, 121, 233-244. [CrossRef]

6. Baştabak, B.; Gödekmerdan, E.; Koçar, G. A holistic approach to soil contamination and sustainable phytoremediation with energy crops in the Aegean Region of Turkey. Chemosphere 2021, 276, 130192. [CrossRef]

7. Lu, H.; Wu, Y.; Liang, P.; Song, Q.; Zhang, H.; Wu, J.; Wu, W.; Liu, X.; Dong, C. Alkaline amendments improve the health of soils degraded by metal contamination and acidification: Crop performance and soil bacterial community responses. Chemosphere 2020, 257, 127309. [CrossRef]

8. Pittet, P.-A.; Josset, M.; Boilley, D.; Bernollin, A.; Rougier, G.; Froidevaux, P. Origin and age of an ongoing radioactive contamination of soils near La hague reprocessing plant based on $239+240 \mathrm{Pu} / 238 \mathrm{Pu}$ and $241 \mathrm{Am} / 241 \mathrm{Pu}$ current ratios and $90 \mathrm{Sr}$ and $\mathrm{Ln}(\mathrm{III})$ soil contents. Chemosphere 2021, 270, 129332. [CrossRef] [PubMed]

9. Ayala, A. In recognition of this special journal issue on real-world emissions on CARB's leadership and central role in uncovering and resolving the environmental violations from Volkswagen's use of illegal diesel defeat devices. Sci. Total Environ. 2018, 642, 1441-1443. [CrossRef] [PubMed]

10. Ziabari, S.-S.H.; Khezri, S.-M.; Kalantary, R.R. Ozonation optimization and modeling for treating diesel-contaminated water. Mar. Pollut. Bull. 2016, 104, 240-245. [CrossRef] [PubMed]

11. Amin Al Manmi, D.A.M.; Abdullah, T.O.; Al-Jaf, P.M.; Al-Ansari, N. Soil and Groundwater Pollution Assessment and Delineation of Intensity Risk Map in Sulaymaniyah City, NE of Iraq. Water 2019, 11, 2158. [CrossRef]

12. Cocârţă, D.; Stoian, M.; Karademir, A. Crude Oil Contaminated Sites: Evaluation by Using Risk Assessment Approach. Sustainability 2017, 9, 1365. [CrossRef]

13. Wu, B.; Lan, T.; Lu, D.; Liu, Z. Ecological and enzymatic responses to petroleum contamination. Environ. Sci. Process. Impacts 2014, 16, 1501-1509. [CrossRef] [PubMed]

14. Rakowska, J. Remediation of diesel-contaminated soil enhanced with firefighting foam application. Sci. Rep. 2020, 10, 8824. [CrossRef]

15. Lu, Y.; Song, S.; Wang, R.; Liu, Z.; Meng, J.; Sweetman, A.J.; Jenkins, A.; Ferrier, R.C.; Li, H.; Luo, W.; et al. Impacts of soil and water pollution on food safety and health risks in China. Environ. Int. 2015, 77, 5-15. [CrossRef] [PubMed]

16. Tsitonaki, A.; Petri, B.; Crimi, M.; Mosbk, H.; Siegrist, R.L.; Bjerg, P.L. In situ chemical oxidation of contaminated soil and groundwater using persulfate: A review. Crit. Rev. Environ. Sci. Technol. 2010, 40, 55-91. [CrossRef]

17. Gao, Y.; Du, J.; Bahar, M.M.; Wang, H.; Subashchandrabose, S.; Duan, L.; Yang, X.; Megharaj, M.; Zhao, Q.; Zhang, W.; et al. Metagenomics analysis identifies nitrogen metabolic pathway in bioremediation of diesel contaminated soil. Chemosphere 2021, 271, 129566. [CrossRef]

18. Abdollahinejad, B.; Pasalari, H.; Jafari, A.J.; Esrafili, A.; Farzadkia, M. Bioremediation of diesel and gasoline-contaminated soil by co-vermicomposting amended with activated sludge: Diesel and gasoline degradation and kinetics. Environ. Pollut. 2020, 263, 114584. [CrossRef]

19. Qin, J.; Zhang, S.; Zhu, Y.; Radian, A.; Long, M. Calcium superphosphate as an inorganic stabilizer for modified-Fenton treatment of diesel-contaminated soil with two different exogenous iron sources. J. Clean. Prod. 2021, 294, 126255. [CrossRef]

20. Homem, V.; Santos, L. Degradation and removal methods of antibiotics from aqueous matrices-A review. J. Environ. Manag. 2011, 92, 2304-2347. [CrossRef]

21. Wang, D.; Xu, H.; Ma, J.; Giannakis, S.; Lu, X.; Chi, H.; Song, S.; Qi, J. Enhanced mineralization of atrazine by surface induced hydroxyl radicals over light-weight granular mixed-quartz sands with ozone. Water Res. 2019, 149, 136-148. [CrossRef]

22. Guo, Z.; Xie, Y.; Xiao, J.; Zhao, Z.-J.; Wang, Y.; Xu, Z.; Zhang, Y.; Yin, L.; Cao, H.; Gong, J. Single-Atom Mn-N 4 Site-Catalyzed Peroxone Reaction for the Efficient Production of Hydroxyl Radicals in an Acidic Solution. J. Am. Chem. Soc. 2019, 141, 12005-12010. [CrossRef]

23. Huang, T.; Chen, D. Kinetics of ozone decomposition in aqueous solution with and without ultraviolet radiation. J. Chin. Inst. Chem. Eng. 1993, 24, 207.

24. Rosal, R.; Rodríguez, A.; Perdigón-Melón, J.A.; Petre, A.; García-Calvo, E.; Gómez, M.J.; Agüera, A.; Fernández-Alba, A.R. Degradation of caffeine and identification of the transformation products generated by ozonation. Chemosphere 2009, 74, 825-831. [CrossRef] [PubMed]

25. Katsoyiannis, I.A.; Canonica, S.; von Gunten, U. Efficiency and energy requirements for the transformation of organic micropollutants by ozone, $\mathrm{O} 3 / \mathrm{H} 2 \mathrm{O} 2$ and UV/H2O2. Water Res. 2011, 45, 3811-3822. [CrossRef]

26. Shi, H.; Chen, L.; Wang, D. Degradation of 2,4-Dichlorophenoxyacetic Acid by O_3 and O_3/H_2O_2. J. Agro-Environ. Sci. 2005, 24, 690-693.

27. Acero, J.L.; Gunten, U. Von Characterization of Oxidation processes: Ozonation and the $\mathrm{AOP} \mathrm{O}_{3} / \mathrm{H}_{2} \mathrm{O}_{2}$. J. Am. Water Works Assoc. 2001, 93, 90-100. [CrossRef]

28. Kusic, H.; Koprivanac, N.; Srsan, L. Azo dye degradation using Fenton type processes assisted by UV irradiation: A kinetic study. J. Photochem. Photobiol. A Chem. 2006, 181, 195-202. [CrossRef]

29. Kim, E.-J.; Park, S.; Adil, S.; Lee, S.; Cho, K. Biogeochemical Alteration of an Aquifer Soil during In Situ Chemical Oxidation by Hydrogen Peroxide and Peroxymonosulfate. Environ. Sci. Technol. 2021, 55, 5301-5311. [CrossRef] 
30. Testolin, R.C.; Mater, L.; Sanches-Simões, E.; Dal Conti-Lampert, A.; Corrêa, A.X.R.; Groth, M.L.; Oliveira-Carneiro, M.; Radetski, C.M. Comparison of the mineralization and biodegradation efficiency of the Fenton reaction and Ozone in the treatment of crude petroleum-contaminated water. J. Environ. Chem. Eng. 2020, 8, 104265. [CrossRef]

31. Zhang, T.; Liu, Y.; Zhong, S.; Zhang, L. AOPs-based remediation of petroleum hydrocarbons-contaminated soils: Efficiency, influencing factors and environmental impacts. Chemosphere 2020, 246, 125726. [CrossRef]

32. Yu, L.; Iranmanesh, S.; Keir, I.; Achari, G. A Field Pilot Study on Treating Groundwater Contaminated with Sulfolane Using $\mathrm{UV} / \mathrm{H}_{2} \mathrm{O}_{2}$. Water 2020, 12, 1200. [CrossRef]

33. Adil, S.; Maryam, B.; Kim, E.-J.; Dulova, N. Individual and simultaneous degradation of sulfamethoxazole and trimethoprim by ozone, ozone/hydrogen peroxide and ozone/persulfate processes: A comparative study. Environ. Res. 2020, 189, 109889. [CrossRef] [PubMed]

34. Cremasco, M.A.; Mochi, V.T. Reaction of dissolved ozone in hydrogen peroxide produced during ozonization of an alkaline medium in a bubble column. Acta Sci. Technol. 2013, 36, 81-85. [CrossRef]

35. Farzaneh, H.; Loganathan, K.; Saththasivam, J.; McKay, G. Ozone and ozone/hydrogen peroxide treatment to remove gemfibrozil and ibuprofen from treated sewage effluent: Factors influencing bromate formation. Emerg. Contam. 2020, 6, 225-234. [CrossRef]

36. Bourgin, M.; Borowska, E.; Helbing, J.; Hollender, J.; Kaiser, H.-P.; Kienle, C.; McArdell, C.S.; Simon, E.; von Gunten, U. Effect of operational and water quality parameters on conventional ozonation and the advanced oxidation process $\mathrm{O}_{3} / \mathrm{H}_{2} \mathrm{O}_{2}: \mathrm{Kinetics}$ of micropollutant abatement, transformation product and bromate formation in a surface water. Water Res. 2017, 122, 234-245. [CrossRef] [PubMed]

37. Falciglia, P.P.; Urso, G.; Vagliasindi, F.G.A. Microwave heating remediation of soils contaminated with diesel fuel. J. Soils Sediments 2013, 13, 1396-1407. [CrossRef]

38. Kogelschatz, U.; Eliasson, B.; Hirth, M. Ozone Generation from Oxygen and Air: Discharge Physics and Reaction Mechanisms. Ozone Sci. Eng. 1988, 10, 367-377. [CrossRef]

39. Do, S.-H.; Jo, J.-H.; Jo, Y.-H.; Lee, H.-K.; Kong, S.-H. Application of a peroxymonosulfate/cobalt (PMS/Co(II)) system to treat diesel-contaminated soil. Chemosphere 2009, 77, 1127-1131. [CrossRef] [PubMed]

40. Mann, H. Non-parametric tests against trend. Econometrica 1745, 13, 163-171.

41. Kendall, M.G. Rank Correlation Methods, 4th ed.; Charles Griffin: London, UK, 1975.

42. Gilbert, R. Statistical Methods for Environmental Pollution Monitoring; John Wiley \& Sons: New York, NY, USA, 1987.

43. EPA. Total Petroleum Hydrocarbons Analysis in Soil by Using Gas Chromatography/Flame Ionization Detector (NIEA S703.62B). Available online: https:/ / www.epa.gov.tw/niea/4BDDD939C0C096FE (accessed on 6 November 2021).

44. Elovitz, M.S.; von Gunten, U. Hydroxyl Radical/Ozone Ratios during Ozonation Processes. I. The R $\mathrm{ct}_{\mathrm{ct}}$ Concept. Ozone Sci. Eng. 1999, 21, 239-260. [CrossRef]

45. Alcantara-Garduño, M.E.; Okuda, T.; Tsai, T.-Y.; Nishijima, W.; Okada, M. Experimental and mathematical evaluation of trichloroethylene removal from saturated soil using acetic acid with saturated ozone. Sep. Purif. Technol. 2008, 60, 299-307. [CrossRef]

46. Siddiqui, M.S.; Amy, G.L.; Murphy, B.D. Ozone enhanced removal of natural organic matter from drinking water sources. Water Res. 1997, 31, 3098-3106. [CrossRef]

47. Chiang, Y.P.; Liang, Y.Y.; Chang, C.N.; Chao, A.C. Differentiating ozone direct and indirect reactions on decomposition of humic substances. Chemosphere 2006, 65, 2395-2400. [CrossRef] [PubMed]

48. Kong, S.-H.; Kwon, C.-I.; Kim, M.-H. Ozone kinetics and diesel decomposition by ozonation in groundwater. Korean J. Chem. Eng. 2003, 20, 293-299. [CrossRef] 